\title{
Media and Politics: Examination on the Political Stance of Kompas in Gus Dur's Impeachment Process
}

\section{Ambang Priyonggo}

Universitas Multimedia Nusantara

ambang@unimedia.ac.ic

\section{ABSTRAK}

Riset ini mencoba menelaah peran politik pers—agen pembangunan, agen penghambat, dan agen perubahan - dalam isu pemakzulan Presiden Abdurrahman Wahid (Gus Dur) di era awal Indonesia memasuki era demokrasi . Dari analisa yang dilakukan dengan metode analisis isi kuantitatif diketahui bahwa Kompas memerankan fungsi sebagai agen penghambat sekaligus juga agen pembangunan. Peran seperti ini menjadi efektif dan strategis bagi demokratisasi Indonesia.

KATA KUNCI: Peran politik, pers, demokrasi

\section{INTRODUCTION}

During the process to the democratic transition in 1990s (in the last years of Soeharto regime), Indonesian press has been recognized to have multiple political roles. In fact in the research done by a political scientist, Duncan McCargo (2003), the Indonesian press was deemed an actor in its own right that could adjust its political modes of agencies to avoid political and economic constraints. The shift of political agencies, from being an agent of stability (developmen journalism or conservative roles) to become an agent of restraint (progressive roles) and an agent of change (transformative roles) happened simultaneously during the last period of Soeharto's semi-authoritarian government in the 1990s, in accordance to the mountingdemandofdemocratisation. McCargo revealed that the political junctures in the country became the main factor of such multiple political roles of media that eventually contributed to the throes of Soeharto re- gime in 1998. The downfall of the regime, indeed, marked the peak of the struggle to the democracy.

Post Soeharto era, Indonesia is stil learning the new democracy that turns out to be uneasy to implement under-many Indonesians call — the multidimensional crisis : political, economy, and social. The new democracy in some way resulted in the freedom of press; however, the complex set of political constellation remains. Since 1998 unti present, there have been three presidential successions within 5 years: from a transitional president B.J Habibie (1999) to democratically elected president Abdurrahman Wahid (19992001), and eventually President Megawati Soekarnoputri (2001-2004), who replaced Wahid regime after he was impeached by parliament under the massive support of media. The rather messy political constellations were also worsened by ethnic/ religious conflicts and separatism issues in some parts of the nations (Moluccas Islands, East Timor, Aceh, West Papua) — tensions that have often been allegedly thought to have connection with the political uncertainty in the capital.

The writer feels that, under such complex set of political settings, the furthe scrutiny on the political roles of press need to be done. The research, using a case study of the most influential and biggest newspaper Kompas Daily, therefore, will identify the roles of the press in the further proces of Indonesian democratic transition. The research looks certain political setting essential to democracy-Abdurrahman Wahid impeachment process (Presidential Decree issue) in 2001 and finds how it affects the political roles of Kompas. Abdurrahman Wahid's impeachment is essential because it is anothe test of the country's never ending political crisis in its early stage of democratic era.

\section{LITERATURE REVIEW}

Several studies have been done in attempts to describe the political roles of media. However, most of the studies merely concentrate on the political communication of media such as election coverage and campaigning. Furthermore, most of the studies of the political roles of media are based upon Western Countries and sometimes have an inadequate relevance to the non-Western countries. Additionally, it is often the case that the study of political roles of media over-ride preoccupation with output, typically studied through content analysis, and often obscure the important process that generate the output (McCargo 2003, p.1)

As the writer would elaborate, there are at least three remarkable works on the political roles of media that are very relevant to this research. The first is done by Timothy E. Cook (1998) who states an argument that media are actually a politica institution and political actor in its own right. Although his research was United States centric, his arguments are essential to put a fundamental concept on the issue, since he comprehensively describes the process of institutionalisation of media from historical, theoretical, and practical point of views.

The second is done by Duncan McCargo (2003). By putting Timothy E. Cook argument to the context of Pacific Asia, including Indonesia, McCargo analyses the process of the simultaneous political roles of media, identifying and elaborating three possible political modes of agencies: an agent of stability, an agent of restraint and an agent of change. The third significant research is done by Susan J. Pharr. In a rather specific context, in Japan, Pharr suggests that media is a trickster, a term she took from the symbolic anthropology (Pharr 1996, pp. 19-43).

\section{Press as a Political Actor}

Timothy E. Cook puts forward an argument to say that media are political actors or political institution in its own right. Cook draws his argument by firstly showing the idea whether the news media are institutional and, secondly, explaining whether it is also political. Cook defines the institutions as follow:

Institutions are social patterns of behavior identifiable across the organizations that are generally seen within a society to preside over a particular social sphere. Although they make choice possible, the practices to particular outcoming given that particular practices cannot be identified as the most beneficial, and all rules are valued in and of thems alves unless and until they demonstrably harm the achievement of important goals.

(Cook, 1998: 70) 
$\mathrm{He}$ further points out that the rules and procedures that comprise institution are valued as usual routines to accomplish certain task, and they also endure over time and extend over space. Such rule and procedure, Cook continues, are also recognizable within organizations that constitute the institution as well as from outside element as having a central part in society and polity (Ibid, 71)

Cook takes the concept on institutions above at a time in his investigation on news media in the United States. Three importan ideas of media institutionalization emerged. The first is news media create the news anchored in distinctive roles, routines, rules and procedures. Secondly, such practices evolved and endured over time and extend across news organizations. Thirdly, the news media are observed by newspersons and nonnewspersons as presiding over a given part of social and political life.

The three issues of institutionalization of media has been used by Cook to justify that media is an institution. Further, he points out that the media is in fact a political actor as well. He argues by firstly pointing to the studies suggesting that political role of media lies in enhancing the reach of those powerful political elites, being influential in "buttressing official authority and less in the allocation of values" (ibid, 86). While in fact, Cook stresses, the case is not as simple as that since he argues that the news media is indeed partially independent from their sources in producing the news content News media may be able to influence who is authoritative, what the values of politics are and which allocation should be made. Making an analogy that the independency of news media is as the same as the other three branches (Executive, Legislative, and Judicative), Cook suggests, "the news media share a similar fate with the three constitutional branches being partially independent from and partially dependent from other institutions for themselves to accomplish their own task" (ibid)

\section{Three Modes of Agencies}

Responding to Cook, Duncan McCargo (2003) elaborates three possible functions of the media under the concept of "political actor/institution". He uses the three possible functions - or McCargo also dubbed them as political mode of agencies-as parameters in determining the process of media roles in Asia Pacific context. Those three possible roles are:

1. Agent of stability

Under this function, the media are prescribed with the task to help the government assist the process of nation building tool under the idea of development journalism.

\section{Agent of Restrain}

The second function of the media is that of day-to-day monitoring of the political order as a watchdog providing checks and balances. As McCargo states, this kind of role "could range from critical editorializing about the government policies to full-scale investigative reporting about high-level of corruption" (McCargo, 2003: 3).

\section{Agent of Change}

Media as Agent of Change put forward idea as a fire-fighting one. In other words, it helps to shape political change during the time of crisis. In an extreme case, it contributes to the downfall of certain political regimes.
McCargo also states that some of these three alternative roles of agencies-stability, restraint, and change — can actually contribute to the democratization process while the othe can do just the opposite. He further states that these three roles are equivalent to the three adjective descriptions of the media' alternative roles: conservative, progressive, and transformative (McCargo 2003, p. 4).

Many may assume that the press implements a specific political role in a given society at a given junctures: an agent of stability in an authoritarian regime (Cuba, Burma); an agent of restraint in a wellestablished democratic state (US, Japan); an agent of change during a time to replace a certain regime (Philippines during Marcos era). However, in practice, the press is actually very polyvalent, multidimensional, and can even adopt the three roles simultaneously, depending on the certain situations. They can be cheering, reproving, and denouncing the power-holders in the same time (Ibid). McCargo's research, therefore, urges the necessity to scrutinize the context of internal political constellations to be able to get a complete idea of the media political roles.

McCargo elsewhere also argues that evaluating the nature of the political roles performed by the media in any given situation requires close examination of two factors: ownership and control of publications,

relationships between owners, journalists, and power-holders (McCargo 1999, p.5). Those two factors, he would say are important to shape the modes of agencies of media in Pacific Asia to become polyvalent and-wisely to say-hypocrite.

Such media hypocrisy also fits with the idea proposed by Susan J. Pharr (1996)
Media and Politics: Examination on the Political Stance of Kompas in Gus Dur's Impeachment Process who states that press is a trickster. She takes the term trickster from the terminology in a symbolic Anthropology in an agrarian society.

The symbolic Anthropoly offers a compelling framework for thinking about the various contradictions in the media role... as a trickster. The trickster is a metaphor for a whole range of stranger-outsiders whose numbers historically have included artsants, artists, minstrel, monkey performers, healers and diviners, clowns and vilage idiots, along with many others.

$$
\text { (Pharr 1996, 25) }
$$

Phar further says that the main characteristic of the trickster figure is its inconsistent social position in relation to the established order: it praises or mocks, badgers or satirizes, horrifies or cajoles (ibid)

\section{METHODOLOGY}

This research is written based on the case study of Kompas Daily conducted by doing content analysis and interviews, using a combination of quantitative and qualitative approach. The choosing of Kompas Daily as a case study is due to the fact that it is the most influential and the biggest circulation newspaper in Indonesia. Secondly, it is reputably known as a publication with a polished style of being objective, accurate, fair, and nonprovocative.

The first primary data are the reports of Kompas Edition of 23 June-23 July 2001, a month period up to the day of impeachment of Abdurrahman Wahid (Presidential Decree issuance). Meanwhile the other primary data are interviews, and the secondary data are the media-watch bulletins, e-resources, journals, conference papers, and other library resources. Concerning the interviews, the writer used structured and semi-structured interviews with six sources. Those 
interviewees are 3 political/media experts, 2 activist journalists/media-watch activists, and 1 politician.

\section{DISCUSSION AND ANALYSIS}

Kompas' Coverage on Presidential Decree

A month up to 23 July 2001 was a critical moment for Indonesia's fragile democratic transition. During the period, the incumbent president Abdurahman Wahid was in an intense dispute with the parliament that was about to impeach him through a Special Session (SI). The impeachment process was ignited by Wahid's erratic style of government. Further the impeachment process was accelerated by two financial scandals involving US $\$ 4.2$ million money (Bulogate and Bruneigate). The issue became crucial to the fate of Indonesian "experimental" democracy as Wahid planned to issue the state of emergency status - through a presidential decree (Dekrit) - that will mean he might have an absolute power, including the right to dissolve the parliament

During such a crisis, there were two broad main groups within the elite and public level: pro-decree and against decree. The pro-decree group was derived from Wahid's faction in parliament (PKB Faction), Democracy activists (especially those who demand the cleansing of New Order people of Golkar) and NU Ulemas (clerics) and NU grassroots. The against-decree group comprises mostly of those pro-reforms faction in parliament, such as Megawati's PDI-P faction, Amien Rais's Reform Faction, and also the "unavoidable" Status Quo Golkar faction. Indeed, in many occasions, military/ police elites had declared their supports to the parliament's impeachment process, being disloyal to the highest commander of Police/ Indonesian Armed Forces: the president.
The against-decree group states that the impeachment process through Special Session is something normal as a democratic mechanism of parliament's check and balance toward the president's performance. In contrast, pro-decree group states that the impeachment process was unconstitutional and a covert scenario of Status Quo Golkar within the parliament trying to collide the reformist politicians with each other. Decree was dubbed by them the best mechanism to dissolve the parliament and Golkar party and to have a new election which is free of New Order's people.

Apart from those two group of against and pro the decree, there is also another group -although politically is no significant - within the elite and public level: neutral. This group just simply calls for an end of the political tension (whether through decree or impeachment) peacefully without sacrificing further interest of the nation and Indonesian people.

As a compromise with parliament was not reached, Wahid issued a presidentia decree on July 22. However, as he lost support from military/police, the decree was not really in effect, and People's Consultative Assembly impeached him through Special Session in the following day and replaced him with his then vice president Megawati Soekarnoputri.

In accordance to the event, the period of 23 June - 23 July 2001 of Kompas's edition is explored to find out the stance and role of the newspaper in this critical situation. Therefore, a closer look on the news focus of the articles related to the issue, type of sources being quoted, and sources' focus is required. The data in Figure 1 shows that on its four type of articles (Main story, National page, Opinion/editorial/polling, and other pages), there are 48 articles related to the issue.
Further, the data reveals an interesting fact regarding the focus of the articles. The distribution of the articles whose focuses are against and neutral are almos equally the same. There are 20 articles $(41 \%)$ against decree and 19 articles $(40 \%)$ neutralwhile only 9 articles (19\%) pro decree.

Although the number of pro-decree ar-

ticles is actually small in overall; however, it

is not the case on its front page (main story)

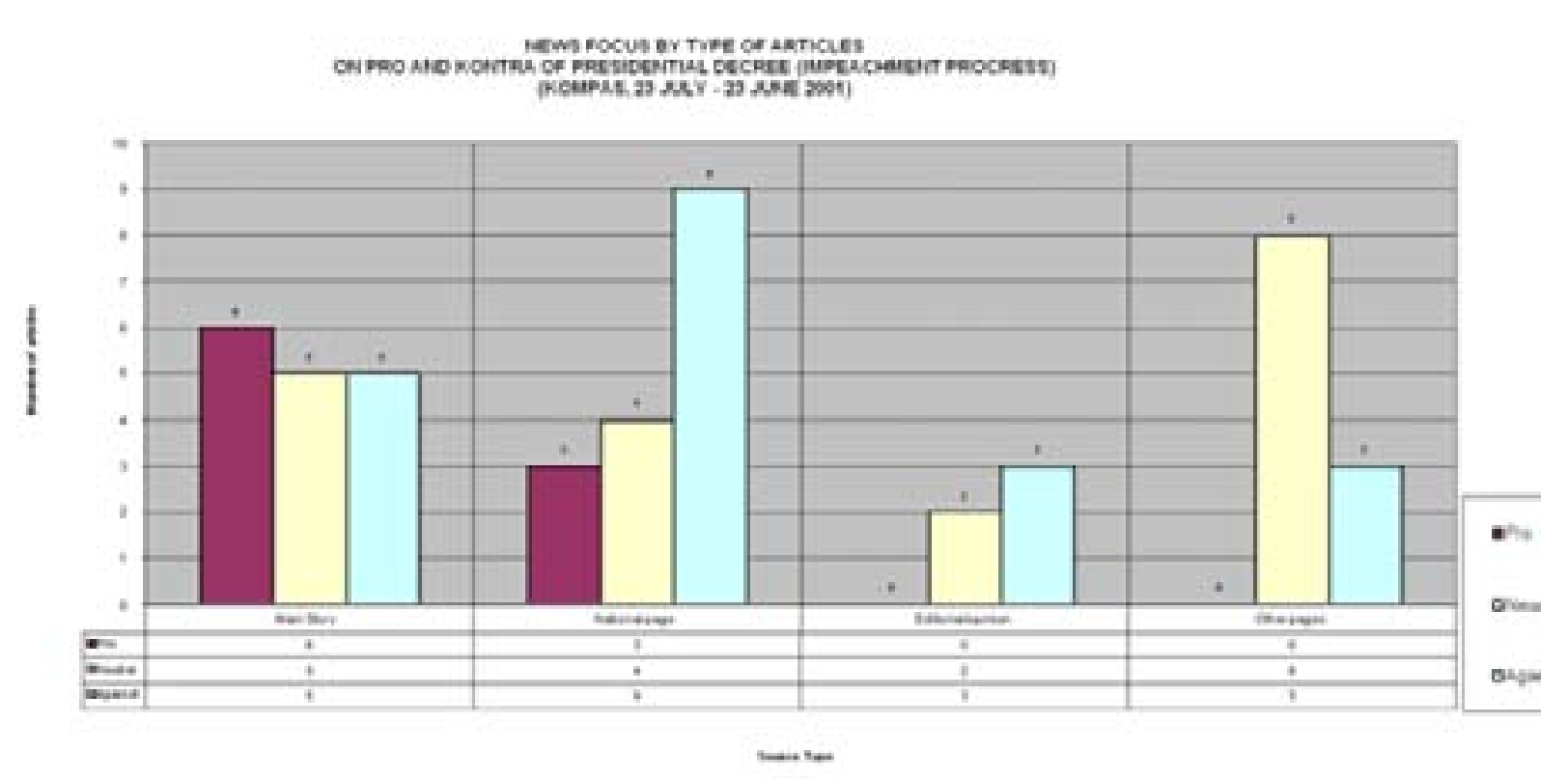

Figure 1

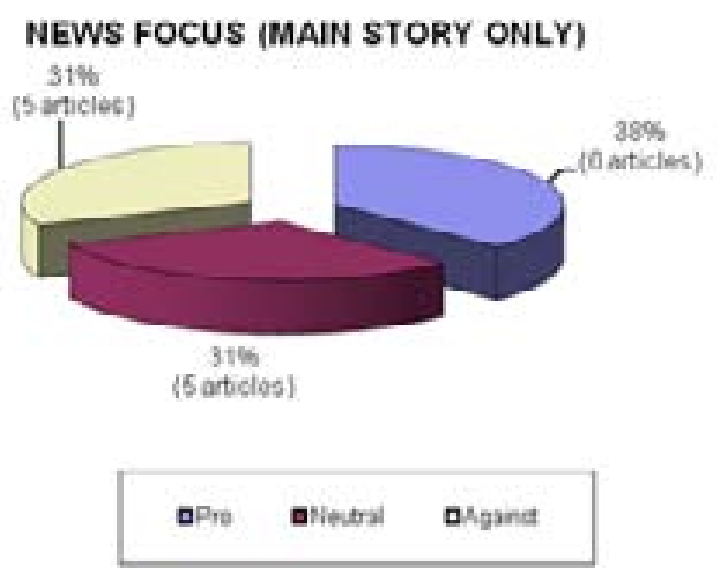

Figure 2
Additionally, on its national and editorial/opinion pages, the news focus of the anti-decree articles dominates with 9 articles (56\%) and 3 articles $(60 \%)$ respectively (Figure 3 and 4). While regarding articles on other pages (regional/business etc), there are 8 articles $(73 \%)$ neutral and 3 articles $(27 \%)$ against the decree-there is, indeed, no

Kompas turns out to be very cautious in reporting the issue on its front page, since the neutral) is almost equally balance. Figure 2 shows that there are 6 articles $(38 \%)$ prodecree, 5 articles (31\%) against decree, and 5 articles $(31 \%)$ neutral. This is probably due to the sensitivity of the event so that the ewspaper tries to give all parties' aspiraarticle on supporting the decree (figure 5) 


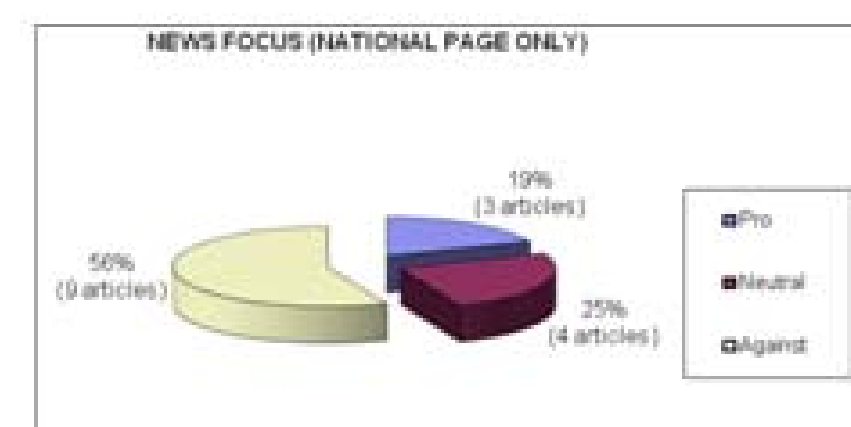

Figure 3

MEWS FOCUS IOPHAONEEDTOFELL OHLV

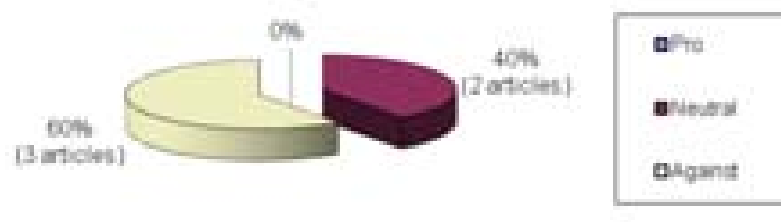

Figure 4

\section{NEWS FOCUS (OTHER PAGES)}

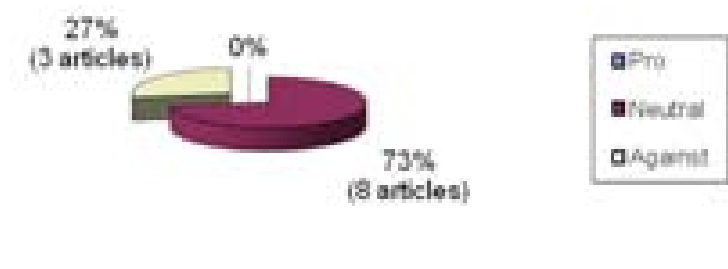

Figure 5

The fact that the news focus of the overall articles is frequently against the presidential decree has raised a question on how the paper accommodates its main sources. As a matter of fact, Figure reveals data that Kompas relies so much on the elite (political and military figures) as main sources being quoted most, apart from academicians/observers and the public. From total 199 sources, 66 of them (55\%) are the elite; 21 of them $(18 \%)$ are academicians/observers; and the remaining 32 of them $(27 \%)$ are the public. It is also important to highlight that within those sources, it turned out that the majority of them are those with neutral views (53 sources). While those with the focus against and pro are 43 sources and 23 sources respectively (figure6). As stated earlier, there are three board-groups: pro, against and neutral. All of the group have their own views and messages to exert: the pro group demand cancellation of Special Session and agree on the issuance of decree; the against group demand Special session and oppose to the decree; the neutral group just simply want all elites to think of the national interests, settling down the political dispute peacefully. While looking at the statistical result alone, Kompas indeed accommodates more of those who are against and neutral, showing its bivalent stance.

\section{Kompas's Political Roles}

Before identifying the paper's political role in this political nuance, it necessitates looking first at its stance and political perspective. The content analysis in sub chapter 4.5 indicates that Kompas's stance is being against and neutral in responding to the president's plan to issue decree. This fact implies the newspaper's views that presidential decree on state of emergency was not a proper mechanism to solve the political dispute between the

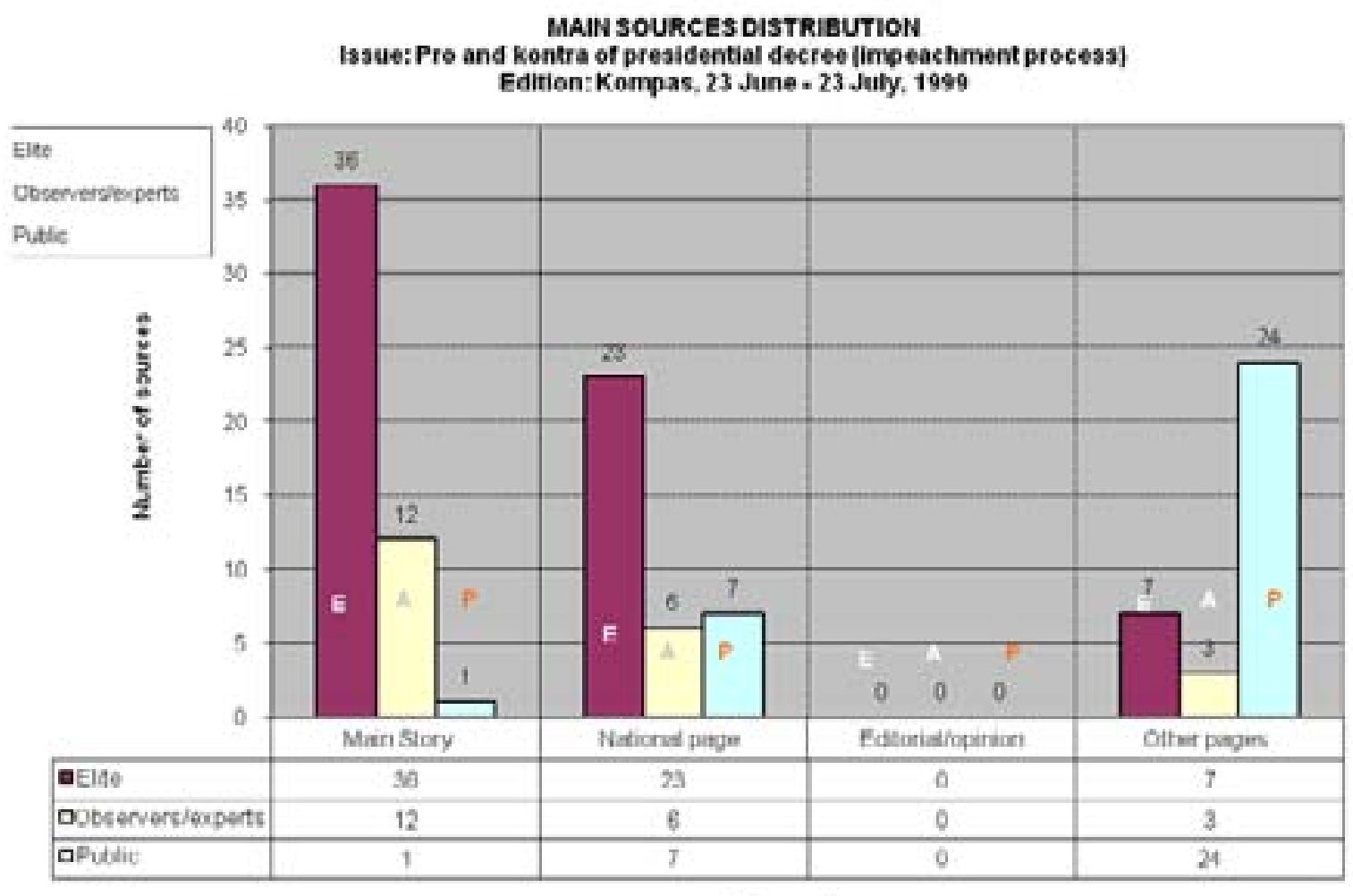

Source Type

FIGURE 6

SOURCES FOCUSOISTAEUTON BYTTPE OF ARTICLES

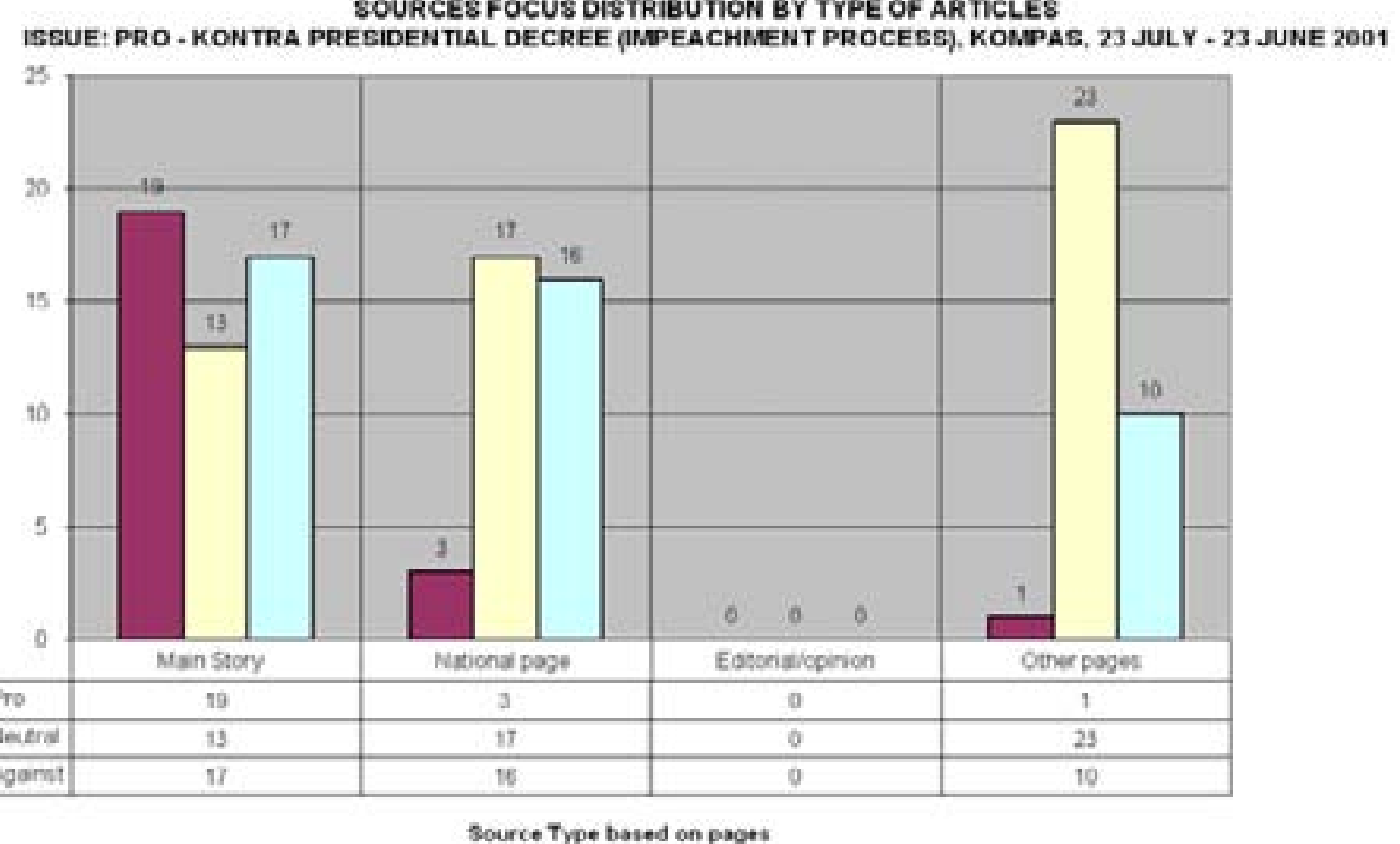


president and parliament. Kompas deemed style of government (including blaming press Special Session of parliament a better of spinning his inconsistent and controversial solution, while in the same time the paper statements) and sudden appearance of two also wielded a neutral message to all the financial scandals (Aribowo Interview).

parties in dispute to put forward the interest of the nation's unity.

Apart from Kompas that was remain "patience, unprovoked, and cautious" Has Kompas's stance and (although still critical) to the situation, sevpolitical views led to the idea that the papers eral big publications like Tempo magazine, performs as agent of change? It is worth Republika and Jawa Pos, for many times noting that Kompas's support on the critically reported stories with the focus on Special Session does not merely lead to the Wahid's financial scandals-moves that the idea that the paper agreed with the incited angers of Wahid's supporters to impeachment to replace Wahid; protest and also occupy several offices of the rather, it saw the process as a publications. Henry Subiakto, a media democratic mechanism of check and expert from Airlangga University, states balance of the president's performance. that Kompas's coverage was not as negative After all, the Special Session was not as other publications, "...rather Kompas's always identical to succession, since in critical stance was focusing on Wahid's such a censure the president might still behaviors such as his high frequency of his defend himself from any misdoings allegedly official trips abroad, instead of centrally accused by the parliament. Asked about the focusing on Bullogate and Bruneigate In fact, during the sud justified such analysis:

"I dare to say that Kompas is very close to Gus Dur (Wahid's nick name) and (there-

fore] it is doubtful to think that the newspa-

per supported the impeachment [to topple

him]. It was rather an impeachment like in

the case of Clinton-Monica scandal...not to

opple him down. It's really not the style of

Kompas to do that

(Ignatius Haryanto Interview)

It was indeed true that at first those two scandals without being supported by Kompas and other publications (including oth- strong data".

er media moda

with the reason that he and his vice-president Megawati were considered to be the perfect combination to bring a better future in presidential decree, it could not be

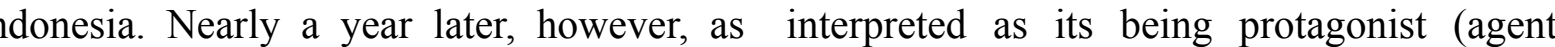
noted by Political Observer Aribowo, Wahid's of change) to demand regime change. honeymoon period with press was on the brink In fact, Kompas actually performed of collapse in accordance to Wahid's erratic the progressive role of press as an agent of restraint, in accordance to the idea of from its own effort by investigating providing check and balance to the established and revealing" While, Aribowo dubs the press at order. Furthermore, the neutral messages that time as merely critical but has yet performed accommodated from neutral group by Kompas investigative journalism (Aribowo Interview). are in accordance to the conservative roles of The notably failure of doing press as an agent of stability, helping preserve investigation was that the press (including of the social order. One point to note, the role Kompas) was unable to seek the truth behind of Kompas as an agent of stability was not the scandals and to explain on why Wahid similar to those media's roles in Soe- for long time remained defiant to attend and harto's New Order era that eventually le- answer the censure in the Special Session and gitimate the power order; rather, the paper insisted a controversial and unconstitutional accommodated the alternative presidential decree. Wahid's financial views that demand animmediate scandals was, in fact, legally unproven and peaceful solution (be it by Special Session he was stated free of the charges by the State or by presidential decree) without scarifying Attorney Office. However, it was too late as the national unity. Accommodating the least parliamenthad already issued the second censure. group's views by Kompas, Media Watch AndwhilewaitingforthefinalcensureintheSpecial Activist Sirikit observed, is valid and ideal. Session,theimpatienceandangryWahidissuedthe "Press, indeed, should accommodate such an unconstitutional presidential decree that alternative voice, although their number is consequently legitimated the parliament to small. That's the essence of democracy...even withdraw his mandatory as a president.

the smallest voice counts/matters" (Sirikit Interview)

Is such bivalent role of Kompas ideal in response to the political crisis at that time? In general, such a bivalent role is by and large ideal, however, there is one thing that needs to be critically noted. Three media analysts being interviewed by the writer contend that the press (including Kompas) during 2001 political crisis still lacked of investigation. Sirikit Syah notices that there was no effor from media to comprehensively investigate the parliament allegations against Wahid on two financial scandals (Bulloggate and Bruneigate) that eventually become the major-force All in all, Kompas, being an agent of leading to the conflict between parliament restraint to provide check and balance to the and the president. Sharing similar views, established order, still requires a role that is Henry Subiakto notes: "About (coverage on) more than just being critical. It needs to perform corruption allegations, (press) still relied on investigations to reveal the truth to be able information which leaks and abounds from the to "educate the audience to understand the political elites in dispute...it's not problem comprehensively" (ibid). 


\section{CONCLUSION}

This research begins with the ide that press is a political actor/institution in its own right. Under such concept, it can play and adopt variety of roles, as being an agent of stability, agent of restraint, and agent of change. Such political roles are not mutually exclusive since they are available to the same media outlets at a different political junctures. In the 1990-1998 (in the last years of Soeharto era), Indonesian political role of press was proven by Duncan McCargo (2003) to adopt the three roles simultaneously, which

eventually brought a positive effect towards the nation's transition to democracy.

In this study, therefore, the writer tried to identify further such roles in the next transition era of democracy (19992002). Looking at the most influential and biggest newspaper, the Kompas Daily, as a case study by observing in 2001 Wahid's impeachment process, the writer is able to prove that press is still a political actor.

Under the political setting, Kompas indeed posed a bivalent role simultaneously: agent of restraint and agent of stability. It changed the role to become an agent of restraints, providing check and balance to the established order and in the meantime being an agent of stability, accommodating an alternative views in accordance to the idea of helping preserve social and political order.

\section{BIBLIOGRAPHY}

Cook, Timothy E. (1998). Governing With the News: the News Media as a Political Institution Chicago: University of Chicago Press.
International Institute for Democracy and Electoral Assistance (IDEA) 2000, 'Democratization in Indonesia: An Assessment (Briefing Paper)'. Paper presented at IDEA Forum for Democratic Reform, Jakarta, 16 Nov.

Mahdi, Waruno (2001). 'Re: Mengapa Gus Dur Masih Satu Kubu Dengan Kita?' in Wahana e-discussion board. Viewed and saved, 14 Feb 2001. Available email: wahana@polarhome.com

McCargo, Duncan. (1999). 'Media and Democratic Transition in South East Asia'. Paper for Panel Discussion on Democracy in the Third World: What should be done, ECPR Joint Session, Manheim, March 26-31.

McCargo, Duncan. (2003). Media and Politics in Pacific Asia, London: Routledge.

Nordholt, Henk Schulte and Irwan Abdullah. (2002). Indonesia in Search of Transition, Workshop paper online - Pustaka Pelajar, Jogjakarta. Viewed: 10 December 2002.

http://www.knaw.nl/Indonesia/transition/ workshop/chapter1 schultenordholt.pdf

Pharr, Susan J. and Ellis S. Krauss. (1996). Media and Politics in Japan, Honolulu: University of Hawaii Press

Sen, Krishna and David T. Hill. (2000). Me dia, Culture and Politics in Indonesia. South Melbourne: Oxford University Press.

Siregar, Amir Effendi. (2002) 'Indonesia: Democracy, Economic Development and the Media'. Paper presented for FIPP/ Asia-Pacific Magazine Media Regiona Conference Seoul. Viewed: 17 October 2002

www.fippseoul.or.kr/fipp/down/amir.pdf
Is Cultural Imperialism a Thing of the Past?

\section{Kristy Nelwan}

Universitas Multimedia Nusantara kristy.nelwan@gmail.com

\section{ABSTRAK}

Teori imperialisme budaya yang menjadi topik hangat perdebatan sosial di skala internasional di awal tahun 1970-an pernah dituduh sebagai paradigma yang bertanggungjawab terhadap serangkaian eksploitasi dan kehancuran budaya di dunia ketiga yang dilakukan oleh negaranegara maju. Sejalan waktu, teori imperialisme budaya dianggap sudah usang dan tidak lagi relevan, terutama berkat sukses berkembangnya industri film lokal serta pemerataan pendidikan lewat jalur beasiswa. Selanjutnya, untuk mencapai keseimbangan dan mengisi kekosongan teori yang ada menyangkut relasi budaya antara dunia pertama dengan dunia ketiga, sejumlah konsep tandingan diusulkan untuk menggantikannya, misalnya dengan konsep globalisasi, atau imperialisme media, yang dianggap tidak berat sebelah. Akan tetapi, dengan menggunakan analisis wacana, penulis akan menunjukkan bahwa ide imperialisme budaya masih tertanam dalam konsep globalisasi, dan terus hidup hingga sekarang, meskipun dalam bentukbentuk yang lebih canggih dan terpoles, sehingga tidak bisa dikatakan bahwa imperialisme budaya merupakan artefak masa lalu.

Kata-kata kunci: imperialisme budaya, globalisasi, imperialisme media.

The cultural imperialism theory emerged as a debate topic among scholars in the early 1970 (Thussu, 2000; Christophers, 2007). Suggesting that the system worked through nations by that time could lead, or probably did already, into serious cultural damage particularly in the Third World countries, cultural imperialism theory gained attention.

There were those who agreed with explanation that an imbalance flow of information was happening, with cultural damage as one of its consequences. Further research and discussion were then performed to, in general, minimize the impact. On the contrary, there were then some who argued that cultural imperialism theory was no longer relevant for many reasons, backed up by sensible case studies.

One of the well known ways to demonstrate the irrelevancy of cultural imperialism theory, popular under the term 'counter cultural imperialism', was through the local film industry (Oliveira, 1993; Jin, 2007). Nevertheless advance study performed by these scholars demonstrated that what happened in the movie industry was not really that promising as fights against cultural imperialism, but more like another shape of cultural imperialism.

The other popular opposition hypothesizes that the same issues and matters are now discussed not under 'cultural imperialism' but the theory of 'Globalisation' (McQuail, 2005; Christophers, 2007; Tomlinson, Cultural Imperialism, 2002; Sakellaropoulos, 2009). Talked mostly about how distance is now not a big problem anymore, thanks to technology that has developed in brisk improvement, globalisation is indeed mentioned in various kind of discipline. Experts on economic/finance/ business, techno- 